\title{
Effects of first-line diabetes therapy with biguanides, sulphonylurea and thiazolidinediones on the differentiation, proliferation and apoptosis of islet cell populations
}

\author{
D. Sarnobat ${ }^{1}$ (D) R. C. Moffett ${ }^{1}$ (D) P. R. Flatt ${ }^{1}$ (D) A. I. Tarasov' ${ }^{1}$ (D)
}

Received: 6 April 2021 / Accepted: 17 June 2021 / Published online: 30 June 2021

(c) The Author(s) 2021

\begin{abstract}
Aims Metformin, rosiglitazone and sulfonylureas enhance either insulin action or secretion and thus have been used extensively as early stage anti-diabetic medication, independently of the aetiology of the disease. When administered to newly diagnosed diabetes patients, these drugs produce variable results. Here, we examined the effects of the three early stage oral hypoglycaemic agents in mice with diabetes induced by multiple low doses of streptozotocin, focusing specifically on the developmental biology of pancreatic islets.

Methods Streptozotocin-treated diabetic mice expressing a fluorescent reporter specifically in pancreatic islet $\alpha$-cells were administered the biguanide metformin $(100 \mathrm{mg} / \mathrm{kg})$, thiazolidinedione rosiglitazone $(10 \mathrm{mg} / \mathrm{kg})$, or sulfonylurea tolbutamide $(20 \mathrm{mg} / \mathrm{kg})$ for 10 days. We assessed the impact of the treatment on metabolic status of the animals as well as on the morphology, proliferative potential and transdifferentiation of pancreatic islet cells, using immunofluorescence.

Results The effect of the therapy on the islet cells varied depending on the drug and included enhanced pancreatic islet $\beta$-cell proliferation, in case of metformin and rosiglitazone; de-differentiation of $\alpha$-cells and $\beta$-cell apoptosis with tolbutamide; increased relative number of $\beta$-cells and bi-hormonal insulin + glucagon + cells with metformin. These effects were accompanied by normalisation of food and fluid intake with only minor effects on glycaemia at the low doses of the agents employed. Conclusions Our data suggest that metformin and rosiglitazone attenuate the depletion of the $\beta$-cell pool in the streptozotocin-induced diabetes, whereas tolbutamide exacerbates the $\beta$-cell apoptosis, but is likely to protect $\beta$-cells from chronic hyperglycaemia by directly elevating insulin secretion.
\end{abstract}

Keywords Oral hypoglycaemic agents · Streptozotocin-induced diabetes $\cdot \alpha$-cells $\cdot$ Beta-cell proliferation ·

Transdifferentiation

\begin{tabular}{ll}
\multicolumn{2}{l}{ Abbreviations } \\
T1D (T2D) & Type 1 (2) diabetes mellitus \\
LADA & Latent autoimmune diabetes of adults \\
YFP & Yellow fluorescent protein \\
OHA & Oral hypoglycaemic agent \\
STZ & Streptozotocin \\
PPAR $\gamma$ & Peroxisome proliferator-activated receptor \\
& type $\gamma$ \\
K $_{\text {ATP }}$ channel & ATP-sensitive potassium channel \\
AMPK & AMP-activated protein kinase
\end{tabular}

A. I. Tarasov

a.tarasov@ulster.ac.uk

1 School of Biomedical Sciences, Ulster University, Cromore Road, Coleraine BT52 1SA, Northern Ireland, UK

\section{Introduction}

Type 2 diabetes (T2D) is a metabolic disease of increasing incidence fuelled by obesity and ageing demographics [1]. Corresponding to $>80 \%$ of the less common type 1 diabetes (T1D) cases [2], latent autoimmune diabetes of adults (LADA) bears close clinical similarity with type 2 diabetes $[3,4]$. Thus, T2D and LADA patients receive an initial treatment with oral hypoglycaemic agents (OHA), which leads to variable results ranging from the attenuation to the progression of the phenotype [4].

The onset of severe diabetes in LADA and T2DM is associated with increased impairment of pancreatic islet hormone secretion, which directly impacts body's glucose homeostasis [5]. The latter is controlled by a concert of two islet antagonising hormones, insulin (secreted by $\beta$-cells) and glucagon $(\alpha$-cells), that ensure glucose clearance from 
or recruitment into the systemic circulation, respectively. Loss of $\beta$-cells, typical to early stages of LADA [6] or later stages of T2DM, is believed to intensify the work of the surviving $\beta$-cell population [3], which enhances the expression of autoantibodies by $\beta$-cells, in LADA [7]. The depletion of $\beta$-cells has been also reported to induce transdifferentiation of other cell types into $\beta$-cells [8-10]. An unidentified signal triggering the compensatory mechanism [8] may involve changes in expression of transcription factors such as the increase in $P d x 1$ [11], Pax4 [12], Ngn3, MafA [13] or loss of Arx [14], Menl [15], Dnmt1 [16]. The plasticity of highly committed pancreatic cells, especially the second-largest population of $\alpha$-cells, is viewed as a tool for regeneration of the $\beta$-cell mass $[8,17]$, an expectation strengthened by reports of therapeutically induced $\alpha$-cell/ $\beta$-cell transdifferentiation $[15,18]$.

An OHA of the thiazolidinedione family with a proven effect on T2DM and LADA progression, rosiglitazone inhibits the activity of PPAR $\gamma$, increasing insulin sensitivity [19] and glucose uptake by adipose tissue and liver [20]. Thiazolidinediones have been also shown to impact various aspects of $\beta$-cell biology [21], such as mitochondrial metabolism [22]. Sulfonylurea tolbutamide targets pancreatic $\beta$-cells directly, by inhibiting the intracellular 'metabolic sensor' [23], ATP-sensitive $\mathrm{K}^{+}$channels, thereby triggering insulin secretion [24]. Historically the oldest OHA, biguanides are believed to impose their glucose-lowering effect by activating AMP-activated protein kinase (AMPK), which inhibits hepatic glucose production [25], possibly affecting the $\beta$-cell function [26].

In the current study, we examined the impact of three oral anti-diabetic agents used for early stage treatment of both T2DM and LADA, rosiglitazone, tolbutamide and metformin, on proliferation and plasticity of pancreatic islet $\alpha$-cell pool, under the conditions of severe $\beta$-cell loss. The latter was modelled in mice bearing an inducible fluorescent label in $\alpha$-cells (Glu ${ }^{\text {CreERT2; }}$ ROSA26e-YFP) that were repeatedly treated with low doses of streptozotocin (STZ) to induce apoptosis in $\beta$-cells, which is expected to provide a critical signal to compensate for the $\beta$-cell loss.

\section{Materials and methods}

\section{Animals}

All experiments, carried out under the UK Animals (Scientific Procedures) Act 1986 and EU Directive 2010/63EU, were approved by the University of Ulster Animal Welfare and Ethical Review Body. Animals were maintained in environmentally controlled rooms at $22 \pm 2{ }^{\circ} \mathrm{C}$ with a $12 \mathrm{~h}$ dark and light cycle and given ad libitum access to standard rodent diet (10\% fat, $30 \%$ protein and $60 \%$ carbohydrate; Trouw Nutrition, Northwich, UK) and water.

\section{Glu $^{\text {CreERT2;ROSA26-eYFP mice }}$}

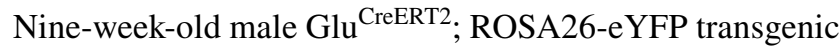
mice were used to perform all studies. An original colony, developed on the C57B1/6 background at the University of Cambridge [27], was subsequently transferred to the animal facility at Ulster University and genotyped to assess Cre-ERT2 and ROSA26eYFP gene expression (Table S1). Three days prior to STZ dosing, mice were injected with tamoxifen (i.p. $7 \mathrm{mg} / \mathrm{mouse}$ ) to activate the tissue-specific expression of yellow fluorescent protein (YFP) in pancreatic islet $\alpha$-cells (Fig. 1A).

\section{Diabetes model and anti-diabetic medications}

Our study was designed to evaluate direct effects of rosiglitazone, tolbutamide and metformin on islet morphology and cell transdifferentiation on background of sustained hyperglycaemia. To exclude the effects mediated by changes of insulin sensitivity or blood glucose (that affect islet composition and function [28, 29]), we used mice with insulindeficient diabetes [30] that was induced by a 5 -day course of injections with STZ (Sigma-Aldrich, Dorset, UK; $50 \mathrm{mg}$ / kg body weight daily, i.p.) ( ${ }^{*}$ MERGEFORMAT Fig. 1A), dissolved in $0.1 \mathrm{M}$ sodium citrate buffer ( $\mathrm{pH}$ 4.5). The animals that underwent STZ injections and developed hyperglycaemia (non-fasting blood glucose $>10 \mathrm{mM}$ [31]) were then divided into 4 groups $(n=6)$ and treated orally, once a day, with saline vehicle, rosiglitazone (TCI, Oxford, UK; $10 \mathrm{mg} / \mathrm{kg}$ ), metformin (TCI, Oxford, UK; $100 \mathrm{mg} / \mathrm{kg}$ ) or tolbutamide (Sigma-Aldrich, Poole, UK; $20 \mathrm{mg} / \mathrm{kg}$ ) for 10 successive days (Fig. 1A). The doses were selected on the basis of ameliorating milder genetic or high-fat-induced [32] but not STZ-induced [33] forms of diabetes, to elucidate the direct effects on islet cell plasticity. Food and fluid intake were assessed every 2 days, whereas blood glucose and body weight were assessed every 4 days. Non-fasting plasma insulin and glucagon were determined at the termination of the study (day 10).

\section{Blood glucose and hormone measurements}

Blood samples were collected from the tail vein of animals into ice-chilled heparin-coated microcentrifuge tubes. Blood glucose was measured using a portable Ascencia meter (Bayer Healthcare, Newbury, Berkshire, UK). For plasma insulin and glucagon, blood was collected in chilled fluoride/ heparin-coated tubes (Sarstedt, Numbrecht, Germany) and centrifuged using a Beckman microcentrifuge (Beckman 
Fig. 1 Rosiglitazone, tolbutamide and metformin partially rescue the diabetic phenotype of the streptozotocin-treated mice. A: Experimental timeline. Antidiabetic treatment starts on day 0 . Tamoxifen is fed to the animals 11 days prior to that to induce the tissue-specific expression of YFP in $\alpha$-cells. STZ is administered to model type 1 diabetes for 5 successive days, 4 days before the start of the treatment. The ability of the latter to improve the diabetic phenotype is then assayed. $B$, $C, D, E$ : Non-fasting blood glucose $(B)$, body weight $(C)$, food $(D)$ and fluid $(E)$ intake of Glu ${ }^{\text {CreERT2 }}$;ROSA26-eYFP mice, following STZ treatment and the administration of antidiabetic drugs, as indicated, for groups of $n=6$ mice each. 'STZ', streptozotocin; 'Rosi', rosiglitazone; 'Tolb', tolbutamide; 'Metf', metformin; 'Ctl', saline control. $F$ : plasma insulin (red) and glucagon (black) $G$ : pancreatic insulin (red) and glucagon (black) content. $F$, $G$ measurements were done on day 10 , in separate groups of mice. ${ }^{*} p<0.05, * * p<0.01$ and $* * * p<0.001$ compared to saline control group. $\Delta p<0.05$, $\Delta \Delta p<0.01, \Delta \Delta \Delta \mathrm{p}<0.001$ compared to the STZ group

A

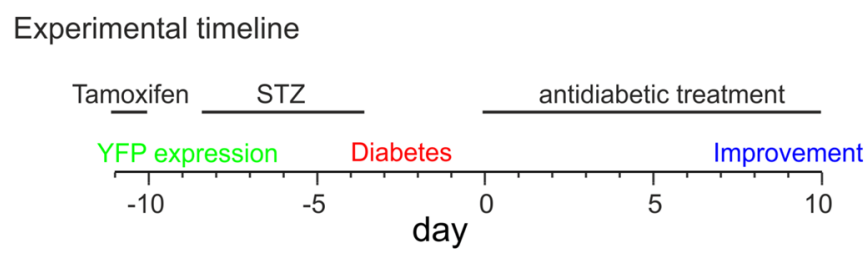

B
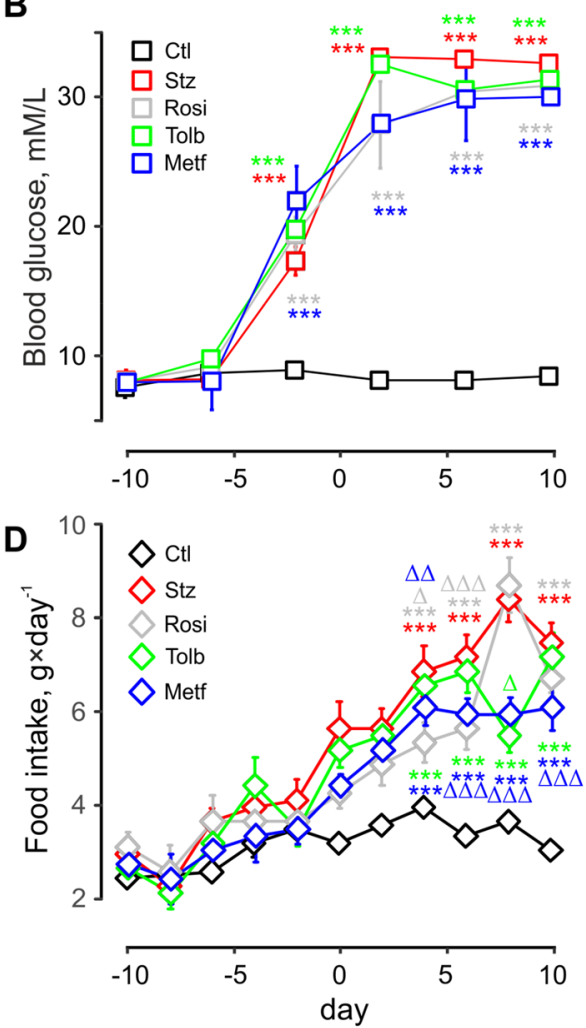

$\mathbf{F}$

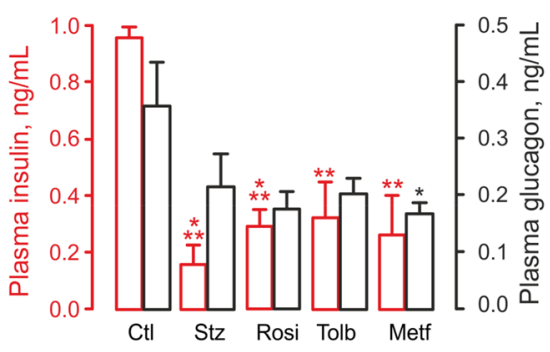

C
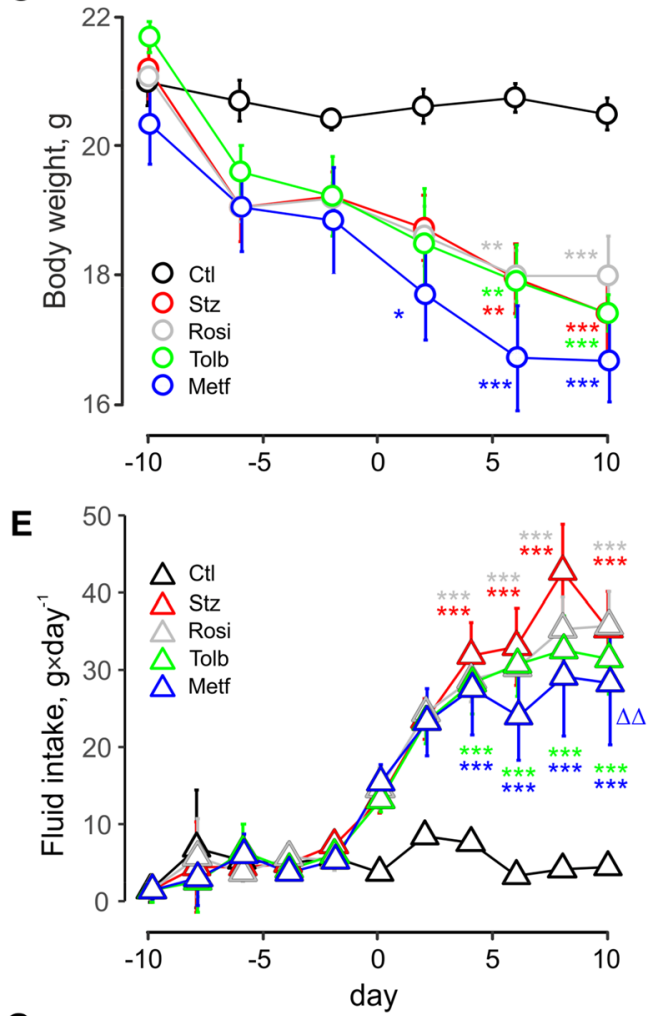

G

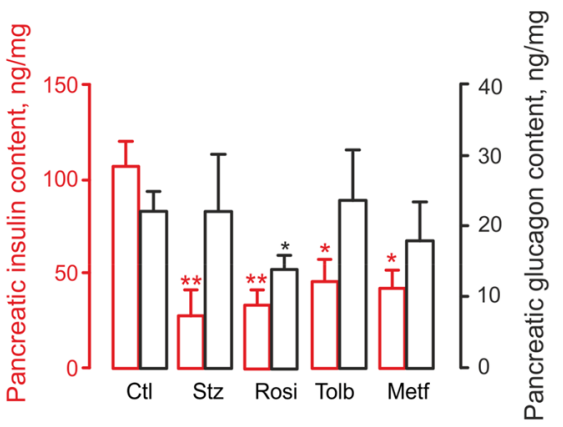

Instruments, Galway, Ireland) for $10 \mathrm{~min}$ at 12,000 rpm. Plasma was then stored at $-20{ }^{\circ} \mathrm{C}$. For hormone determination from tissues, samples underwent acid-ethanol extraction ( $\mathrm{HCl}: 1.5 \% \mathrm{v} / \mathrm{v}$, ethanol: $75 \% \mathrm{v} / \mathrm{v}, \mathrm{H}_{2} \mathrm{O}: 23.5 \%$ $\mathrm{v} / \mathrm{v})$. Insulin concentrations were subsequently assessed by an in-house radioimmunoassay [34]. Plasma glucagon and pancreatic glucagon content were measured using glucagon ELISA (EZGLU-30 K, Merck Millipore), or RIA kit (250tubes GL-32 K, Millipore, USA), respectively.

\section{Immunohistochemistry and imaging}

Following the removal of pancreatic tissue, samples were cut longitudinally and fixed with $4 \%$ PFA for $48 \mathrm{~h}$ at $4{ }^{\circ} \mathrm{C}$. Fixed tissues were embedded and processed for antibody staining as described [30]. Tissue Sects. $(7 \mu \mathrm{m})$ were blocked with $2 \%$ BSA and incubated with respective primary antibodies overnight at $4{ }^{\circ} \mathrm{C}$, and, subsequently, with appropriate secondary antibodies (Table S2). To stain nuclei, a final incubation was carried out at $37{ }^{\circ} \mathrm{C}$ with $300 \mathrm{nM}$ DAPI (Sigma-Aldrich, D9542). To assess cell proliferation and/or 
apoptosis, co-staining of mouse anti-insulin (Abcam, Cambridge, UK; 1:1000; ab6995) or guinea pig anti-glucagon (PCA2/4, 1:200; raised in-house) with rabbit anti-Ki-67 (1:200; Abcam ab15580) or TUNEL reaction mixture (Roche Diagnostics Ltd, UK) was used. YFP, indicating the $\alpha$-cell lineage, was detected by with a rabbit anti-GFP antibody (1:1000; Abcam, ab6556) (Table S2), which is reactive against all variants of Aequorea Victoria GFP, including YFP. The slides were imaged on an Olympus BX51 microscope, equipped with a 40x/1.3 objective. We aimed to include all the islets visible on the slide in the morphometry analysis, independently of their localisation in relation to other pancreatic structures, with at least 50 cells analysed within each islet cross-section in the per-cell studies (Figs. 2B, 3). The multichannel fluorescence was recorded using DAPI (excitation $350 \mathrm{~nm} / \mathrm{emission} 440 \mathrm{~nm}$ ), FITC (488/515) and TRITC (594/610) filters and a DP70 camera controlled by $\mathrm{Cell}^{\mathrm{F}}$ software (Olympus, UK). Images were analysed using ImageJ software. All counts were determined in a blinded manner with $60-150$ islets analysed per treatment group, as indicated in the figure legends. The non-stained cells visible in the middle of the islet were not excluded from the computation of the islet area.

\section{Data analysis and statistics}

Statistical analysis was performed using PRISM 5.0 (GraphPad, USA) or R. Values are expressed as mean \pm SEM.
A

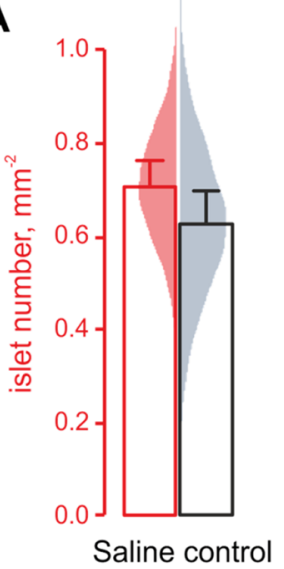

B

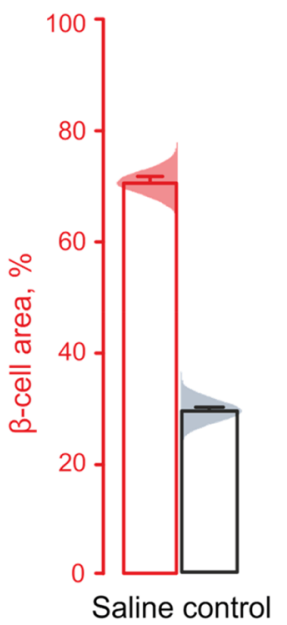

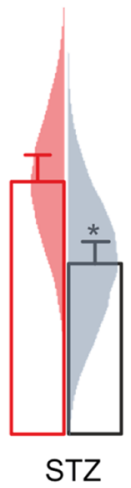

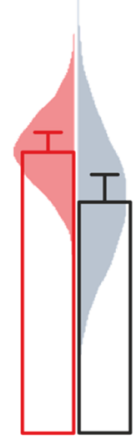

Rosiglitazone Tolbutamide

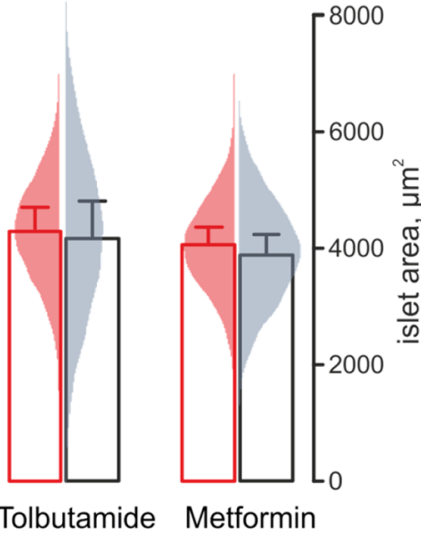

$\mathrm{C}_{\text {insulin glucagon DAPI }}$
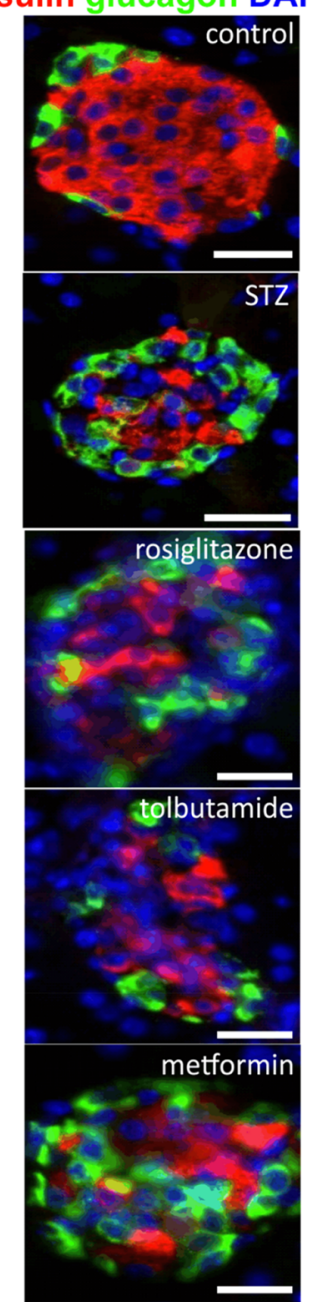

Fig. 2 Diabetic phenotype is associated with changes in the islet composition. Impact of the administration of STZ to

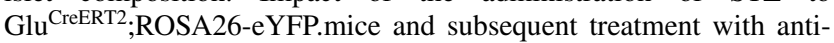
diabetic drugs, as indicated, on: islet number (black, $\mathrm{n}=150$ islets from 6 mice) and islet area (red, $n=150$ islets from 6 mice) $(A)$; $\beta$ - (red, $n=150$ islets from 6 mice) and $\alpha$-cell (black, $n=150$ islets from 6 mice) percentage among the islet cells $(B)$. $C$ : Representative immunostaining of mouse pancreatic sections for DAPI (blue), glucagon (green) and insulin (red). $* p<0.05$ and $* * * p<0.001$ compared to the saline control group. $\Delta p<0.05$ compared to streptozotocintreated group. Scale bars: $50 \mu \mathrm{m}$ 
Comparative analyses between experimental groups were carried out using independent-samples Student's $t$ test or (for $>2$ samples) a one-way ANOVA with Bonferroni's post hoc. The difference between groups was considered significant for $p<0.05$.

\section{Results}

\section{STZ-induced intake of food and fluid is partially rescued by the anti-diabetic drugs}

The treatment with STZ resulted in a progressive diabetic phenotype in the mice, which was reflected by the elevation of blood glucose concentration (Fig. 1B). Non-fasting blood glucose increased in the STZ-treated mice from $8.2 \pm 0.4 \mathrm{mM}$ (end of the STZ treatment) to $32.6 \pm 0.4 \mathrm{mM}$ 14 days afterwards $(7.6 \pm 0.7$ and $8.4 \pm 0.6 \mathrm{mM}$, respectively, in the control group).

As designed, 10-day administration of rosiglitazone, tolbutamide or metformin had no significant impact on glycaemia $(30.8 \pm 0.7,31.3 \pm 0.4,30.0 \pm 0.1 \mathrm{mM}$, respectively) (Fig. 1B). The onset of hyperglycaemia coincided with the $9 \%$ decrease in the body weight from $19.2 \pm 0.4 \mathrm{~g}$ at the end of the STZ treatment $(20.7 \pm 0.3 \mathrm{~g}$ in the control group, n.s.) to $17.4 \pm 0.4 \mathrm{~g}$ after 14 days $(20.5 \pm 0.3 \mathrm{~g}$ in the control group, $p<0.05$ ) (Fig. 1C). 10-day administration of rosiglitazone and tolbutamide had no statistically significant impact on body weight $(17.9 \pm 0.6,17.4 \pm 0.3 \mathrm{~g}$, respectively, $p<0.05$ vs control), whereas metformin tended to exacerbate $(16.7 \pm 0.6 \mathrm{~g}, p<0.05$ vs control) the weight loss (Fig. 1C).

The effects of STZ treatment on the intake of food or fluid by the experimental animals were palpable 4 days post its cessation (day 0, Fig. 1D,E) and were progressively elevating from that point. Both food and fluid intake were significantly attenuated after 4 days of treatment with metformin (Fig. 1D,E), coincident with the decrease in the body weight (Fig. 1C). Neither of the remaining two OHA influenced fluid intake (Fig. 1E); however, rosiglitazone and, at one point, tolbutamide significantly attenuated the intake of food (Fig. 1D).

As a result of the STZ treatment, the non-fasting terminal plasma insulin levels that were measured on day 10 were substantially decreased $(0.16 \pm 0.06$ vs $0.95 \pm 0.04 \mathrm{ng} / \mathrm{mL}$ in STZ-treated and control groups, $P<0.01$ ), whereas the differences between corresponding glucagon levels did not attain statistical significance $(0.19 \pm 0.07$ vs $0.32 \pm 0.11 \mathrm{ng} /$ $\mathrm{mL}$ ) (Fig. 1F). Whilst none of the OHA elevated insulin levels (Fig. 1F), metformin induced a significant decrease of plasma glucagon levels, on the STZ-treatment background $(0.15 \pm 0.03$ vs $0.32 \pm 0.11 \mathrm{ng} / \mathrm{mL}$ in the control group, $p<0.05$ ) (Fig. 1F).
In line with the effect on plasma hormone levels (Fig. 1F), STZ substantially decreased pancreatic content of insulin $(27.5 \pm 9.9$ vs $109.2 \pm 8.0 \mathrm{ng} / \mathrm{mg}$ of tissue in control, $p<0.05)$, without any appreciable effect on the glucagon content (Fig. 1G). Following subsequent rosiglitazone treatment, the glucagon content was substantially decreased $(13.3 \pm 3.8$ vs $22.7 \pm 4.2 \mathrm{ng} / \mathrm{mg}$ of tissue in control, $p<0.05)$, whereas tolbutamide or metformin had no effect on this parameter (Fig. 1G).

\section{The alleviation of the diabetic phenotype is associated with a mild effect on the islet composition}

We did not detect any significant alteration in the islet number, in response to any treatments (red in Fig. 2A). At the same time, the observed decrease in plasma and pancreatic insulin (Fig. 1F,G) coincided with the decrease in the average cross-section area of islets in the STZ-treated mice (black in T Fig. 2A). The OHA therapy that followed the STZ treatment resulted in a mild increase in this metric (black in Fig. 2A).

The STZ treatment produced a significant reduction in the relative $\beta$-cell area (red/insulin + in Fig. $2 B, C)$ and, respectively, an increase in the relative $\alpha$-cell area (black/ glucagon + in Fig. 2B,C). Remarkably, a 10-day oral administration of metformin, but not rosiglitazone or tolbutamide, counter-acted the effects of the STZ treatment, resulting in small but significant differences in the percentage of $\beta$-cells $(55 \pm 2 \%$ vs $48 \pm 2 \%$ in STZ mice, $p<0.05)$ and $\alpha$-cells $(44 \pm 2 \%$ vs $51 \pm 2 \%$ in STZ mice, $p<0.05$ ) (Fig. 2B,C). Interestingly, the islets from the STZ-treated animals contained a palpable fraction of cells that did not express insulin or glucagon (Fig. 2C): we need to stress that, among other types, islets contain significant numbers of vascular endothelial cells [35, 36], which are likely to contribute to this phenomenon.

\section{Oral hypoglycaemic agents increase proliferation but have no effect on apoptosis of $\beta$-cells}

In line with the report of STZ inducing $\beta$-cell apoptosis, when used in small repeated doses [37], we observed a sixfold $(2.2 \pm 0.1$ vs $0.4 \pm 0.1 \%$ in control mice, $\mathrm{p}<0.05)$ increase in the percentage of $\beta$-cells expressing an apoptosis marker, TUNEL, in STZ-treated mice (red, Fig. 3A, Figure S1A). The metformin therapy tended to attenuate the $\beta$-cell apoptosis, whereas tolbutamide further increased the expression of TUNEL by $\beta$-cells ( $3.2 \pm 0.3 \%$ vs $2.2 \pm 0.1$ in the STZ-treated mice, $p<0.05$ ) (red, Fig. 3A). Although the STZ treatment per se has not affected the apoptosis of $\alpha$-cells (black, Fig. 3A), metformin administered to the STZ-treated animals mildly increased this characteristic $(0.5 \pm 0.1 \%$ 

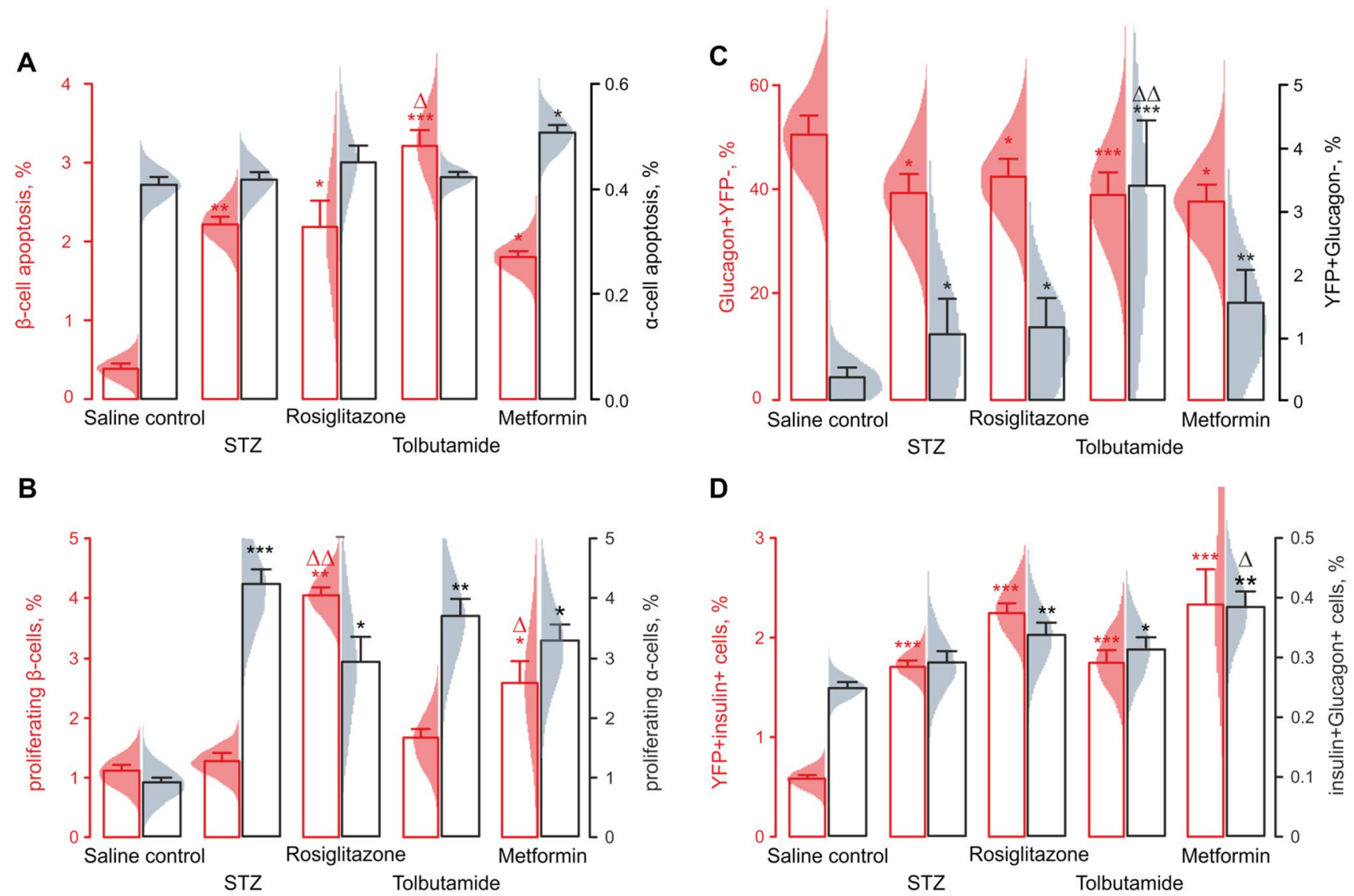

Fig. $3 A, B$ : Percentage of $\beta$-cells (red, $n=60$ islets from 6 mice) and $\alpha$-cells (black, $n=60$ islets from 6 mice) undergoing apoptosis $(A)$, as determined by TUNEL staining, or proliferation $(B)$, ki67 staining, in

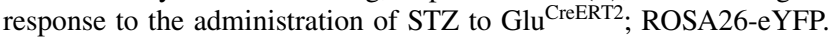
mice and subsequent treatment with anti-diabetic drugs, as indicated. Grey bars in $B$ represent the net difference in the proliferating fractions of $\alpha$ - and $\beta$-cells. $C, D$ : Trans-differentiation of YFP + cells within Glu ${ }^{\mathrm{CrERT}}$;ROSA26-eYFP.mice. The YFP expression, origi-

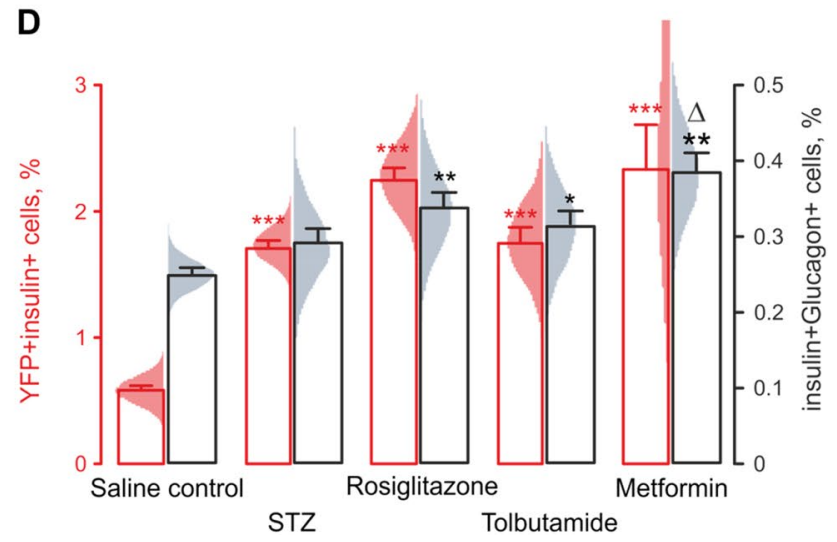

nally specifically induced in $\alpha$-cells, was detectable within $\alpha$-cells ( $C$, red, $n=60$ islets from 6 mice), non- $\alpha$-cells ( $C$, black, $n=60$ islets from 6 mice) and $\beta$-cells ( $D$, red, $n=60$ islets from 6 mice) after to the administration of STZ and subsequent anti-diabetic treatment. In addition, double-positive (insulin + glucagon + ) cells were detectable ( $D$, black, $n=60$ islets from 6 mice). $* p<0.05, * * p<0.01$ and $* * * p<0.001$ compared to saline control group. $\Delta p<0.05$ and $\Delta \Delta p<0.01, \Delta \Delta \Delta p<0.001$ compared to STZ-treated group [35]

vs $0.4 \pm 0.1 \%$ in the STZ-treated group, $p<0.05$ ) (black, Fig. 3A, Figure S1A).

The pro-apoptotic effect of the STZ treatment did not affect the percentage of proliferating $\beta$-cells, as was assayed via Ki-67 staining (red, Fig. 3B, Figure S1B). This metric was increased by subsequent treatment with rosiglitazone or metformin $(4.0 \pm 0.2 \%$ and $2.5 \pm 0.4 \%$ respectively, vs $1.3 \pm 0.1 \%$ in the STZ-treated group, $p<0.05)$. The STZ treatment produced a fivefold increase in the fraction of proliferating $\alpha$-cells (black in Fig. 3B, Figure S1B), which was not affected by any of the OHA (black in Fig. 3B).

\section{Long-term administration of oral hypoglycaemic agents does not affect $\alpha-/ \beta$-cell transdifferentiation}

The key feature of the animal model used in this study, the $\mathrm{Glu}^{\mathrm{CreERT2}}$; ROSA26-eYFP mice, is the tissue-specific targeting (pancreatic $\alpha$-cells) and the inducible nature of the

expression of YFP. When co-detected with anti-glucagon antibodies, 20 days post-induction of the targeted YFP expression, the islets from these mice had only a small fraction of YFP + cells that did not express glucagon $(0.3 \pm 0.1 \%)$ (black, Fig. 3C, Figure S1C). The YFP + cell percentage was increased almost threefold after the STZ treatment $(0.8 \pm 0.4 \%, p<0.05 \mathrm{vs}$ control $)$ and further potentiated by tolbutamide $(2.7 \pm 0.8 \%, p<0.005$ vs control, $p<0.01$ vs STZ) but not rosiglitazone or metformin $(0.9 \pm 0.4 \%, p<0.05$ vs control and $1.2 \pm 0.4 \%, p<0.01$ vs control, respectively) (black, Fig. 3C, Figure S1C). Of note, we were unable to detect YFP in almost half of glucagon ${ }^{+}$ cells, which we believe to reflect a technical feature of the anti-GFP antibody staining (red in Fig. 3C).

The percentage of the $\mathrm{YFP}^{+}$insulin ${ }^{+}$cells was low in the experimental animals with $\alpha$-cell-specific targeting of YFP $(0.6 \pm 0.1 \%$ in the control group). The treatment with STZ however triplicated this number $(1.7 \pm 0.1 \%)$ (red, 
Fig. 3D, Figure S1D). Neither of the OHA was able to further enhance the commitment of the YFP + cells towards the insulin lineage (red, Fig. 3D). At the same time, the administration of each of the OHA, following the STZ treatment, increased the percentage of bi-hormonal (insulin + glucagon + ) cells (black, Fig. 3D, Figure S1D). The size of this small cell subpopulation was unaffected by the STZ treatment $(0.27 \pm 0.01 \%$ vs $0.25 \pm 0.02 \%$ in the control group), whereas subsequent rosiglitazone $(0.33 \pm 0.02 \%)$, tolbutamide $(0.31 \pm 0.02 \%)$ and metformin $(0.38 \pm 0.03 \%)$ administration substantially expanded it (black, Fig. 3D).

\section{Discussion}

We probed the mechanisms whereby the oral hypoglycaemic agents may partially compensate for the selective apoptotic damage of $\beta$-cells. In our hands, pancreatic $\beta$-cell population was partially replenished via increased proliferation, in response to metformin or rosiglitazone, whereas tolbutamide exacerbated apoptosis, arguably by putting an extra demand on insulin production and secretion mediated by cytosolic $\mathrm{Ca}^{2+}[38]$.

\section{Diabetic phenotype of the mice}

The diabetes model and the OHA dosage were designed to resolve the direct effects of the OHA on pancreatic islet cell plasticity [39]. We have opted for repeated injections of small doses of STZ $[9,40]$ over high-fat diet or leptin receptor deficiency animal models of diabetes to enable cell lineage tracing and rule out any indirect effects, mediated by changes in insulin sensitivity or blood glucose, that may impact the islet plasticity. The model animals displayed stably elevated glycaemia and reduced body weight (Fig. 1B,C), whereas the three treatments, at the doses chosen, affected only food and fluid intake (Fig. 1D,E). Notably, the doses used compare well with daily human recommended doses, given the differences in the pharmacokinetics of the three drugs in the mouse and human systems [41-43].

\section{Islet mass, morphology, apoptosis and proliferation of $\beta$ - and $\alpha$-cells}

A side effect of the OHA therapy, lowering of the systemic glucagon in response to metformin (Fig. 1F), is unlikely to reflect the depletion of the $\alpha$-cell population due to its transdifferentiation or apoptosis, as $\alpha$-cells are well in excess, in rodent islets $[35,44]$. The phenomenon could have stemmed from the elevation of circulating GLP-1 levels, reported to be induced by metformin [45]. Another possible explanation for this effect is the activation of the intra-islet GLP-1 secretion system [46-48], under the conditions of the STZ treatment $[9,49]$. The likely mechanism for that is the acquisition of the proconvertase PC1/3 activity by $\alpha$-cells [46], with a subsequent shift in the $\alpha$-cell secretory output from glucagon to GLP-1. In line with the reported cytostatic effect of metformin [50] that, in our hands, stimulated apoptosis in $\alpha$-cells (but, surprisingly, given earlier reports [51], not in $\beta$-cells, Fig. 3A), the elevation of intra-islet and circulating GLP-1 could explain partial recovery of the ratio of $\beta$ - and $\alpha$-cells (Fig. 2B), presumably by upregulating $\beta$-cell proliferation $[9,30]$. Notably, rosiglitazone, reported to increase the $\beta$-cell mass by reversing the apoptosis [52], was not efficient in doing so in our model (Fig. 3A). In our hands, it induced a fourfold increase of the proliferating $\beta$-cells, in line with the previous reports [52].

\section{Effects of OHA on alpha cell transdifferentiation}

The STZ-induced $\beta$-cell injury per se resulted in a detectable expression of insulin and a loss of expression of glucagon by $\mathrm{YFP}^{+}$cells (Fig. 3C), reflecting the $\alpha$-cell population before the STZ treatment. The fact that none of the OHA affected the co-expression of insulin and YFP on a per-cell basis suggests the lack of a role in regulating $\alpha-/ \beta$-cell transdifferentiation (Fig. 3D).

In the present study, a small but detectable number of bi-hormonal [8] cells was evident after the STZ treatment, followed by administration of metformin (Fig. 3D). This effect can be explained by non-pancreatic signals [53] that may induce $\alpha$-cell transdifferentiation. On the contrary, the de-differentiation of $\alpha$-cells by tolbutamide (Fig. 3C), likely to result from a direct effect on the $\mathrm{K}_{\mathrm{ATP}}$ channels, was not associated with any $\beta$-cell phenotype.

\section{Relative merits of different OHAs}

Since sulphonylureas are actively prescribed for diabetes, further elucidation of their global effects on islet function is highly relevant. No previous study has reported, to our knowledge, on the effects of this drug class on islet cell transdifferentiation. Our data with tolbutamide are important in revealing that not only does the sulphonylurea lack beneficial effects on islet plasticity (unlike the two other classes of OHA) but that it exerts adverse effects on $\beta$-cell health and apoptosis. This can be viewed as a significant limitation of first-line sulphonylurea therapy and would suggest that incretin mimetics which have recently shown to have positive effects on $\beta$-cell transdifferentiation, apoptosis and proliferation $[9,29]$ would be a better therapeutic option for direct $\beta$-cell actions. 


\section{Conclusion}

Alongside peptide hormones [9, 40], small molecules have been shown to induce transdifferentiation of pancreatic $\alpha$-cells into $\beta$-cells. Metformin and rosiglitazone but not tolbutamide promoted the restoration of the $\beta$-cell pool via proliferation, with none of the three oral anti-diabetic drugs affecting the $\alpha$-cell transdifferentiation induced by the loss of $\beta$-cells. In contrary, metformin decreased the islet $\alpha$-cell population via apoptosis, whereas tolbutamide, in turn, enhanced apoptosis in $\beta$-cells. Whether these drugs impose similar effects in humans, alongside the reported antioxidant [54] and insulinotropic [55] activity, remains the matter of future research.

Supplementary Information The online version contains supplementary material available at https://doi.org/10.1007/s40618-021-01620-6.

Acknowledgements These studies were supported in part by Young Investigator Award from Diabetes UK to RCM and Ulster University Vice-Chancellor Research Studentship award to DS. We thank Fiona Gribble and Frank Reimann (Cambridge University) for the gift of $\mathrm{Glu}^{\mathrm{CreERT2}}$; ROSA26e-YFP mice.

\section{Declarations}

Conflicts of interest statement Authors declare no conflicts of interest.

Research involving human participants and/or animals All experiments, carried out under the UK Animals (Scientiic Procedures) Act 1986 and EU Directive 2010/63EU, were approved by the University of Ulster Animal Welfare and Ethical Review Body.

Informed consent No human participants were involved, hence the informed consent does not apply.

Open Access This article is licensed under a Creative Commons Attribution 4.0 International License, which permits use, sharing, adaptation, distribution and reproduction in any medium or format, as long as you give appropriate credit to the original author(s) and the source, provide a link to the Creative Commons licence, and indicate if changes were made. The images or other third party material in this article are included in the article's Creative Commons licence, unless indicated otherwise in a credit line to the material. If material is not included in the article's Creative Commons licence and your intended use is not permitted by statutory regulation or exceeds the permitted use, you will need to obtain permission directly from the copyright holder. To view a copy of this licence, visit http://creativecommons.org/licenses/by/4.0/.

\section{References}

1. Chobot A, Górowska-Kowolik K, Sokołowska M, Jarosz-Chobot P (2018) Obesity and diabetes-not only a simple link between two epidemics. Diabetes/metabolism Res Rev 34:e342

2. Ahlqvist E, Storm P, Käräjämäki A et al (2018) Novel subgroups of adult-onset diabetes and their association with outcomes: a data-driven cluster analysis of six variables. Lancet Diabetes Endocrinol 6:361-369

3. Cernea S, Buzzetti R, Pozzilli P (2009) $\beta$-cell protection and therapy for latent autoimmune diabetes in adults. Diabetes Care 32:S246-S252

4. Liang H, Cheng Y, Tang W et al (2019) Clinical manifestation and islet $\beta$-cell function of a subtype of latent autoimmune diabetes in adults (LADA): positive for T cell responses in phenotypic type 2 diabetes. Acta Diabetol 56:1225-1230

5. Moffett RC, Patterson S, Irwin N, Flatt PR (2015) Positive effects of GLP-1 receptor activation with liraglutide on pancreatic islet morphology and metabolic control in C57BL/KsJ db/ $\mathrm{db}$ mice with degenerative diabetes. Diabetes Metab Res Rev $31: 248-255$

6. Jörns A, Wedekind D, Jähne J, Lenzen S (2020) Pancreas pathology of latent autoimmune diabetes in adults (LADA) in Patients and in a LADA rat model compared with type 1 diabetes. Diabetes 69:624-633

7. Björk E, Kämpe O, Andersson A, Karlsson F (1992) Expression of the $64 \mathrm{kDa}$ /glutamic acid decarboxylase rat islet cell autoantigen is influenced by the rate of insulin secretion. Diabetologia 35:490-493

8. Thorel F, Népote V, Avril I et al (2010) Conversion of adult pancreatic $\alpha$-cells to $\beta$-cells after extreme $\beta$-cell loss. Nature 464:1149-1154

9. Sarnobat D, Moffett CR, Tanday N et al (2020) Antidiabetic drug therapy alleviates type 1 diabetes in mice by promoting pancreatic $\alpha$-cell transdifferentiation. Biochem Pharmacol. https://doi.org/10. 1016/j.bcp.2020.114216

10. Chera S, Baronnier D, Ghila L et al (2014) Diabetes recovery by age-dependent conversion of pancreatic $\delta$-cells into insulin producers. Nature 514:503-507

11. Yang Y-P, Thorel F, Boyer DF, Herrera PL, Wright CV (2011) Context-specific $\alpha$-to- $\beta$-cell reprogramming by forced Pdx 1 expression. Genes Dev 25:1680-1685

12. Collombat P, Xu X, Ravassard P et al (2009) The ectopic expression of Pax4 in the mouse pancreas converts progenitor cells into $\alpha$ and subsequently $\beta$ cells. Cell 138:449-462

13. Matsuoka T-a, Kawashima S, Miyatsuka T et al (2017) Mafa enables Pdx1 to effectively convert pancreatic islet progenitors and committed islet $\alpha$-cells into $\beta$-cells in vivo. Diabetes 66:1293-1300

14. Wilcox CL, Terry NA, Walp ER, Lee RA, May CL (2013) Pancreatic $\alpha$-cell specific deletion of mouse Arx leads to $\alpha$-cell identity loss. PLoS ONE 8(6):e66214

15. Lu J, Herrera PL, Carreira C et al (1958) (2010) $\alpha$ cell-specific men 1 ablation triggers the transdifferentiation of glucagonexpressing cells and insulinoma development. Gastroenterology 138:1954-1965

16. Chakravarthy H, Gu X, Enge M et al (2017) Converting adult pancreatic islet $\alpha$ cells into $\beta$ cells by targeting both Dnmt 1 and Arx. Cell Metab 25:622-634

17. Puri S, Folias AE, Hebrok M (2015) Plasticity and dedifferentiation within the pancreas: development, homeostasis, and disease. Cell Stem Cell 16:18-31

18. Ackermann AM, Moss NG, Kaestner KH (2018) GABA and artesunate do not induce pancreatic $\alpha$-to- $\beta$ cell transdifferentiation in vivo. Cell Metab 28:787-792

19. Boughton CK, Munro N, Whyte M (2017) Targeting beta-cell preservation in the management of type 2 diabetes. British J Diabetes 17:134-144

20. Kavak S, Ayaz L, Emre M (2012) Effects of rosiglitazone with insulin combination therapy on oxidative stress and lipid profile in left ventricular muscles of diabetic rats. Experim Diabetes Res. https://doi.org/10.1155/2012/905683 
21. Gupta D, Kono T, Evans-Molina C (2010) The role of peroxisome proliferator-activated receptor $\gamma$ in pancreatic $\beta$ cell function and survival: therapeutic implications for the treatment of type 2 diabetes mellitus. Diabetes Obes Metab 12:1036-1047

22. Jamwal S, Blackburn J, Elsworth JD (2020) PPAR $\gamma / P G C 1 \alpha$ signaling as a potential therapeutic target for mitochondrial biogenesis in neurodegenerative disorders. Pharmacol Therapeut. https://doi. org/10.1016/j.pharmthera.2020.107705

23. Dabrowski M, Tarasov A, Ashcroft FM (2004) Mapping the architecture of the ATP-binding site of the KATP channel subunit Kir6. 2. J Physiol 557:347-354

24. Tarasov AI, Welters HJ, Senkel S et al (2006) A Kir6.2 mutation causing neonatal diabetes impairs electrical activity and insulin secretion from INS-1 beta-cells. Diabetes 55:3075-3082

25. Apostolova N, Iannantuoni F, Gruevska A, Muntane J, Rocha M, Victor VM (2020) Mechanisms of action of metformin in type 2 diabetes: Effects on mitochondria and leukocyte-endothelium interactions. Redox Biol. https://doi.org/10.1016/j.redox.2020. 101517

26. Sun G, Tarasov A, McGinty J et al (2010) Ablation of AMPactivated protein kinase $\alpha 1$ and $\alpha 2$ from mouse pancreatic beta cells and RIP2. Cre neurons suppresses insulin release in vivo. Diabetologia 53:924-936

27. Campbell JR, Martchenko A, Sweeney ME, et al (2019) Essential role of Munc18-1 in the regulation of glucagon-like peptide-1 secretion. https://tspace.library.utoronto.ca/handle/1807/98201

28. Brereton MF, Rohm M, Ashcroft FM (2016) $\beta$-Cell dysfunction in diabetes: a crisis of identity? Diabetes Obes Metab 18:102-109

29. Tanday N, Flatt PR, Irwin N, Moffett RC (2020) Liraglutide and sitagliptin counter beta-to alpha-cell transdifferentiation in diabetes. J Endocrinol 245:53-64

30. Vasu S, Moffett RC, Thorens B, Flatt PR (2014) Role of endogenous GLP-1 and GIP in beta cell compensatory responses to insulin resistance and cellular stress. PLoS ONE. https://doi.org/ 10.1371/journal.pone.0101005

31. Ando H, Ushijima K, Shimba S, Fujimura A (2016) Daily fasting blood glucose rhythm in male mice: A role of the circadian clock in the liver. Endocrinology 157:463-469

32. McKillop AM, Stevenson CL, Moran BM, Abdel-Wahab YH, Flatt PR (2018) Tissue expression of DPP-IV in obesity-diabetes and modulatory effects on peptide regulation of insulin secretion. Peptides 100:165-172

33. Tahara A, Matsuyama-Yokono A, Nakano R, Someya Y, Hayakawa M, Shibasaki M (2009) Effects of the combination of dipeptidyl peptidase-IV inhibitor ASP8497 and antidiabetic drugs in streptozotocin-nicotinamide-induced mildly diabetic mice. Eur J Pharmacol 605:170-176

34. Flatt P, Bailey C (1981) Abnormal plasma glucose and insulin responses in heterozygous lean (ob/+) mice. Diabetologia 20:573-577

35. Tarasov AI, Galvanovskis J, Rorsman O et al (2018) Monitoring real-time hormone release kinetics via high-content 3-D imaging of compensatory endocytosis. Lab Chip 18:2838-2848

36. Adam J, Ramracheya R, Chibalina MV et al (2017) Fumarate Hydratase Deletion in Pancreatic beta Cells Leads to Progressive Diabetes. Cell Rep 20:3135-3148

37. O'brien BA, Harmon BV, Cameron DP, Allan DJ (1996) Betacell apoptosis is responsible for the development of IDDM in the multiple low-dose streptozotocin model. J Pathol 178:176-181

38. Efanova IB, Zaitsev SV, Zhivotovsky B et al (1998) Glucose and tolbutamide induce apoptosis in pancreatic $\beta$-Cells a process dependent on intracellular $\mathrm{Ca} 2+$ concentration. J Biol Chem 273:33501-33507

39. Brereton MF, Iberl M, Shimomura K et al (2014) Reversible changes in pancreatic islet structure and function produced by elevated blood glucose. Nat Commun 5:1-11
40. Sarnobat D, Moffett RC, Gault VA et al (2019) Effects of longacting GIP, xenin and oxyntomodulin peptide analogues on alphacell transdifferentiation in insulin-deficient diabetic GluCreERT2; ROSA26-eYFP mice. Peptides. https://doi.org/10.1016/j.peptides. 2019.170205

41. Kulkarni NM, Malampati S, Mahat MYA et al (2016) Altered pharmacokinetics of rosiglitazone in a mouse model of nonalcoholic fatty liver disease. Drug Metabol Personal Therapy 31:165-171

42. Cox PJ, Ryan DA, Hollis FJ et al (2000) Absorption, disposition, and metabolism of rosiglitazone, a potent thiazolidinedione insulin sensitizer, in humans. Drug Metab Dispos 28:772-780

43. Gross AS, Bridge S, Shenfield GM (1999) Pharmacokinetics of tolbutamide in ethnic Chinese. Br J Clin Pharmacol 47:151-156

44. Hamilton A, Zhang Q, Salehi A et al (2018) Adrenaline stimulates glucagon secretion by Tpc2-dependent $\mathrm{Ca}(2+)$ mobilization from acidic stores in pancreatic alpha-Cells. Diabetes 67:1128-1139

45. Bahne E, Sun EW, Young RL et al (2018) Metformin-induced glucagon-like peptide- 1 secretion contributes to the actions of metformin in type 2 diabetes. JCI insight. https://doi.org/10.1172/ jci.insight. 93936

46. Marchetti P, Lupi R, Bugliani M et al (2012) A local glucagon-like peptide 1 (GLP-1) system in human pancreatic islets. Diabetologia 55:3262-3272

47. Taylor SW, Nikoulina SE, Andon NL, Lowe C (2013) Peptidomic profiling of secreted products from pancreatic islet culture results in a higher yield of full-length peptide hormones than found using cell lysis procedures. J Proteome Res 12:3610-3619

48. Chambers AP, Sorrell JE, Haller A et al (2017) The role of pancreatic preproglucagon in glucose homeostasis in mice. Cell Metabol 25:927-934.e923

49. Campbell SA, Golec D, Hubert M et al (2020) Human islets contain a subpopulation of glucagon-like peptide-1 secreting $\alpha$ cells that is increased in type 2 diabetes. Molec Metabol. https://doi. org/10.1016/j.molmet.2020.101014

50. Queiroz EA, Puukila S, Eichler R et al (2014) Metformin induces apoptosis and cell cycle arrest mediated by oxidative stress, AMPK and FOXO3a in MCF-7 breast cancer cells. PLoS ONE. https://doi.org/10.1371/journal.pone.0098207

51. Kefas BA, Cai Y, Kerckhofs K et al (2004) Metformin-induced stimulation of AMP-activated protein kinase in $\beta$-cells impairs their glucose responsiveness and can lead to apoptosis. Biochem Pharmacol 68:409-416

52. Holloway A, Petrik J, Bruin J, Gerstein H (2008) Rosiglitazone prevents diabetes by increasing beta-cell mass in an animal model of type 2 diabetes characterized by reduced beta-cell mass at birth. Diabetes Obes Metab 10:763-771

53. Tarasov AI, Rorsman P (2016) Dramatis personae in $\beta$-cell mass regulation: enter serpinb1. Cell Metab 23:8-10

54. Masini M, Anello M, Bugliani M et al (2014) Prevention by metformin of alterations induced by chronic exposure to high glucose in human islet beta cells is associated with preserved ATP/ADP ratio. Diabetes Res Clin Pract 104:163-170

55. Lupi R, Marchetti P, Giannarelli R et al (1997) Effects of glibenclamide and metformin (alone or in combination) on insulin release from isolated human pancreatic islets. Acta Diabetol $34: 46-48$

Publisher's Note Springer Nature remains neutral with regard to jurisdictional claims in published maps and institutional affiliations. 